\title{
The whole and the nothing much
}

Commentary on the GZ Lecture 2021 "Nothing much geographies” by Chris Philo

In his article "Nothing much geographies", Chris Philo has committed to the task of introducing Adorno's intricacies of Minima Moralia (MM) to current academic geography. MM represents an ambitious project of "rescuing [objects] as he does from the multiple, intersecting tyrannies of diverse belief systems, intellectual formulations and practical (ab)usage" (Philo 2021, 2) - not through analyzing great and salient phenomena, not through comprehensive or systematic cataloging, nor through accounting for "the victor's version of history" (ibid., 12), but through aphoristic strips of thought on "very small things". But the role that the "small things" play here, as Philo ultimately shows, is immense: the fragmented descriptions of "nothing much" are said to be nothing less than "the last hope for thought" (MM, 67). Moreover, what Adorno works out in MM spreads through other writings as well and signifies a new approach to the "conceptualization of objects" (Philo 2021, 21). This approach introduces the non-identical, "the importance of what remains, the differences, the unassimilable" (ibid., 16). Philo carefully reconstructs a "gaze averted from the beaten track" as with Adorno's approach in MM: "the goal is to excavate what gets obscured by standard accounts; to retrieve what gets assimilated to the point of invisibility and unthinkability, but which can still be discerned by the critical micrologist" (ibid., 13).

Nothing much geographies builds productive but also critical connections between this unique oeuvre of the Frankfurt School's key thinker and current geographical debates. In particular, it speaks to discourses on non-representational and more-than-human-geographies, the 'geographies without scale' debate, and, last but not least, a dialectical and negative approach and the role anti-fascism should play in these debates (and beyond). Philo vouches for Adorno's concern with the things that too often escape the geographical imagination the little things, the "near distanced" position we have toward them and the endurance (the 'lingering') that the researcher should hold in order to explore them. This 'micrology' is calibrated for geographies of the "nothing-much".

The push to have geographers to look at the things in front of their noses is absolutely convincing. For instance, the COVID pandemic, our post-colonial responsibility and climate justice are substantially changing the way modern-day geographers should analyze and engage with the world. Near-distanced, slower-paced and little things need more attention and care; they need to grow on us. But the proposed use of Adorno's gaze in geography should not be applied without a sincere reflection on his background in social critique. This means that the 'micrology' of MM does not entail a retreat from the big questions and contexts, as they are always folded into the little things, they "damage" 
and hurt them. Geographies of the "nothing-much" are also geographies of "everything": Throughout Adorno's work, the concept of totality always lingers, such that MM really appears to be a very earnest attempt to critique and evade its grasp. Philo's essay engages thoroughly with methodological considerations in MM, but seems shy about carrying forward what motivated Adorno as he wrote MM and other works: The term totality, for Adorno, refers to how the capitalist law of exchange and the resulting patterns of domination and instrumentalism structure the whole of society. He and other members of the Frankfurt school believed the capitalist system permeates everything - down to the very possibility of forming knowledge. Totality, how its (damaged) objects and subjects are situated in it, and how we can analyze and critique it, was Adorno's main interest. Because of its multivalence, Adorno himself held a complex intellectual position, settled between philosophy and sociology, building often on Freud, Marx and Hegel (Philo 2021, 4), but also on Weber, Nietzsche and Rousseau. That is why in the Frankfurt Institute for Social Research (IfS, or in English ISR) Horkheimer, Habermas and Adorno each held double academic chairs in both sociology and philosophy. In fact, they believed a reciprocal interweaving of the two epistemologies to be essential to researching society. So it is no wonder that the goal of MM, as stated in the dedication, is the search for "the teaching of the good life". By tradition, this is the program of "moralias", philosophical works set at the nexus of individual conduct and society.

But Adorno finds life in a "damaged" form, therefore one has to separate "what life is" from what it has become: "the sphere of private existence and now of mere consumption, dragged along as an appendage of the process of material production, without autonomy or substance of its own" (MM, 15). The obstacles this project faces are high: "Our perspective of life has passed into an ideology which conceals the fact that there is life no longer. [...] Means and end are inverted" (ibid.). Hence "ideology" is accused of averting the gaze from what "the critical scholar must seek", to escape "the flatland of capitalist exchange" (Philo 2021, 15 f.) and avoid mere "surface phenomenology of things" (ibid., 17). In other words, Adorno claims that the ideological "context of delusion" is total, absorbing everything and everyone in a monopoly of meaning. Moreover, "it is part of the mechanism of domination to forbid recognition of the suffering it produces $[\ldots]$ " (MM, 63), to obfuscate and blur. The totality, "which would suffer nothing to remain outside of it $[\ldots]$ ", saturates and distorts everything (MM, 16). This is why for instance Horkheimer, Adorno, and Fromm were always skeptical about purely empirical research, as the collected material from social and political phenomena is always predetermined through the totality of capitalist society. There is no data untouched by the ideological "context of delusion", as Adorno specifically works out in his essay "sociology and empirical research": "Theoretical reflections upon society as a whole cannot be completely realized by empirical findings; they seek to evade the latter [...]." (Adorno 1976, 68). Instead, his suggested approach strives for empirics and theory to work together in dialectical relationship: "The conceptual dichotomy of induction and deduction is the scientistic (sic!) substitute for dialectics" (ibid., 75). The ever-churning cycle of induction and deduction of Adorno's dialectical approach secures a counter-movement to "traditional science", which in turn "wishes to rid the world of the ten- 
sion between the general and the particular by means of its consistent system, but the world gains its unity from inconsistency" (ibid., 77).

In a similar way this has been described in the essay "traditional and critical theory" from 1937 by Max Horkheimer, which serves as a programmatic introduction to critical theory and the Frankfurt School's way of thinking. In this text, a deep unease with the conditions of knowledge acquisition is clear: "They [the branches of science] are moments in the social production process." (Horkheimer 1957, 171). The problem is not only rooted in capitalist society, but reaches into the very conditions of perception: "The facts, which are brought to us by our senses are doubly shaped by society: through the historical character of the perceived object and through the historical character of the perceiving organ." (Horkheimer 1994, 174). Or as Adorno has put it: "Isolated social research becomes untrue as soon as it wishes to extirpate totality as a mere crypto-metaphysical prejudice, since totality cannot, in principle, be apprehended by its methods. Science then pledges itself to the mere phenomena." (Adorno 1976, 78). This illustrates why the thinkers of Frankfurt School so clearly lean towards theory and rebuke purely empirical research as ideologically contorted. It is theory, the endeavor to strip ideology off the social phenomenon, that can overcome the problem of empiricist limits: "It must dissolve the rigidity of the temporally and spatially fixed object into a field of tension of the possible and the real: each one, in order to exist, is dependent upon the other. In other words, theory is indisputably critical." (ibid., 67). Social research becomes critical only when it reflects on itself in a theoretical mode, scrutinizing its methodical and cognitive conditions, creating fields of tension and possibility. But it can never fully dissolve the contradiction between reflection and analysis, which is why it has to remain in the critical and negative mode. "A concept of society that is not satisfied with this [repeating of familiar concepts], would be critical" (Adorno 2003, 13). The negative and critical method is an act of self-defense against the damaging totality of capitalist society, which he deemed very powerful - and dangerous: "The totality context is of such a form that everyone must obey the law of exchange, in order not to perish" (Adorno 2003, 14). In contrast to Marx's famous eleventh thesis on Feuerbach', and to what his students held against him during the ' 68 uprisings, Adorno did not seek to change the world, but to interpret it more carefully - in order to not lapse from one damaging condition into the next.

Critical theory therefore always seeks to keep the societal totality in mind, in order to approximate truth in spite of the ideologically contorted conditions. This is what MM tries to do, as Adorno has laid out and conceptualized in his more systematic texts, for instance in his Negative Dialectics (Philo 2021, 3). MM is a tentative application. It puts Adorno's methodological reflections to work and creates pieces of truly critical research. This means several things: First, that they are not purely empirical, but theory-borne, even speculative (e.g. Adorno 2015, 68). Second, they do not define the phenomena, but rather free them from their usual definition, to circumvent their

1 All translations from German to English were done by the author.

2 "Philosophers have hitherto only interpreted the world in various ways; the point is to change it." Source: https://www.marxists.org/archive/marx/works/1845/theses/theses.pdf. 
objectification. Third, to avoid any instrumentalism or purpose of thought, as Philo has made clear (Philo 2021, 11), Adorno is moving towards the small, the petty and otherwise neglected things - "the nothing-much", the purposeless, the non-identical (ibid., 1). But this is not a negation of totality and the whole or a retreat towards the isolated, but rather an embracing of it, as every aphorism reflects on and bears witness to the damages inflicted on these things by the totality of domination. "There are hardly any phrases in Adorno's work that do not contain both society and the individual at the same time. The move towards the whole is characteristic for Adorno's way of thinking", as Axel Honneth has expressed it (Seitz 2021). This is why I hold the concept of totality and its relation to the objects (and subjects - but this goes too far at this point) to be essential for recreating 'Adorno's gaze' and his 'micrology' for human geography. Moreover, the dialectical tension, as the driver of critical knowledge acquisition, is exceptionally strong when we look at the fragmentary, little, unimportant things with the whole in mind. Therefore, fostering this tension might be favorable to the critical power of the gaze: "Total purposelessness gives the lie to the totality of purposefulness in the world of domination, and only by virtue of this negation, which consummates the established order by drawing the conclusion from its own principle of reason, has existing society up to now become aware of another that is possible" (Adorno 2003, $224 \mathrm{f}$.). In short: in the light of the negative dialectical approach, the little things of MM are "nothing-much", as much as they are "everything" at the same time - displaying the radiance of another world that is possible.

\section{References}

Adorno, T.W. (2005[1952]): Minima Moralia. Reflections from damaged life, London/New York: Verso.

Adorno, T. W. (1976): "Sociology and Empirical Research", in The Positivist Dispute in German Sociology, ed. ibid., London: Heinemann, pp. 68-86.

Adorno, T.W. (2003): "Gesellschaft”, in Soziologische Schriften 1, Frankfurt: Suhrkamp, pp. 9-19.

Horkheimer, M. (1994 [1937]): Traditionelle und Kritische Theorie. Fünf Aufsätze, Frankfurt: Suhrkamp.

Seitz, N. (2021): Das Ganze der Welt im Blick zu behalten. Seminar Sitzungsprotokolle von Theodor W. Adorno, in: aus Deutschlandfunk 11.02.2021, retrieved from https://www.deutschlandfunk. de/seminar-sitzungsprotokolle-von-theodor-w-adorno-das-ganze.1148.de.html?dram:article $\mathrm{id}=492365$ 05.03.202, last seen 15.03.2021

\section{JANIKA KUGE}

Humangeographie Universität Freiburg, Schreiberstr. 20, 79098 Freiburg,

Janika.kuge@geographie.uni-freiburg.de 